\title{
UPAYA MENINGKATKAN KEMAMPUAN GURU DALAM MENGGUNAKAN POWER POINT MELALUI IN-SERVICE TRAINING
}

\author{
Mulyani \\ SD Negeri 2 Saradan \\ Saradan, Baturetno, Kabupaten Wonogiri, Jawa Tengah 57673 \\ Email: mulyanisamidi13@gmail.com
}

\begin{abstract}
Abstrak
Penelitian ini bertujuan untuk meningkatkan Kemampuan Guru Dalam Menggunakan Program Power Point Presentation Sebagai Media Pembelajaran di SD Negeri 2 Saradan pada semester 1 Tahun Pelajaran 2019/2020. Penelitian ini menggunakan bentuk Penelitian Tindakan Sekolah (PTS) yang dilaksanakan dalam 2 (dua) siklus, dilaksanakan di SD Negeri 2 Saradan dengan subjek penelitian adalah guru SD Negeri 2 Saradan Tahun Pelajaran 2019/2020 yang berjumlah 8 orang guru. Penilaian kemampuan guru dilakukan dengan teknik observasi dengan lembar observasi. Validasi data dilakukan dengan teknik triangulasi. Analisis data dilakukan dengan teknik analisis deskriptip komparatif. Berdasarkan data empiris diperoleh fakta bahwa melalui penerapan in-service training dapat meningkatkan kompetensi guru SD Negeri 2 Saradan semester 1 Tahun Pelajaran 2019/2020 dalam penguasaan pembelajaran berbasis Program Power Point Presentation Sebagai Media Pembelajaran. Dapat disimpulkan bahwa melalui in-service training Kemampuan Guru Dalam Menggunakan Program Power Point Presentation Sebagai Media Pembelajaran SD Negeri 2 Saradan pada semester 1 Tahun Pelajaran 2019/2020 dapat ditingkatkan.

Kata kunci: kemampuan guru, Program Power Point Presentation, Media Pembelajaran, in-service training
\end{abstract}

\begin{abstract}
This study aims to improve the ability of teachers to use the Power Point Presentation Program as a Learning Media at SD Negeri 2 Saradan in semester 1 of the 2019/2020 academic year. This study uses the form of School Action Research (PTS) which is carried out in 2 (two) cycles, carried out at SD Negeri 2 Saradan with the research subjects being teachers at SD Negeri 2 Saradan for the 2019/2020 academic year, totaling 8 teachers. The teacher's ability assessment is carried out by using observation techniques with observation sheets. Data validation is done by triangulation technique. Data analysis was carried out using comparative descriptive analysis techniques. Based on empirical data, it is found that through the implementation of in-service training, teachers of SD Negeri 2 Saradan in semester 1 of the 2019/2020 academic year can be obtained in mastering learning based on the Power Point Presentation Program as a Learning Media. It can be concluded that through in-service training the teacher's ability to use the Power Point Presentation Program as a Learning Media at SD Negeri 2 Saradan in semester 1 of the 2019/2020 academic year can be improved.
\end{abstract}

Keywords: teacher ability, Power Point Presentation Program, Learning Media, in-service training

\section{PENDAHULUAN}

Kegiatan pembelajaran merupakan hal yang paling pokok dalam keseluruhan proses pendidikan di sekolah. Hal tersebut berarti pencapaian tujuan pendidikan banyak bergantung kepada bagaimana proses pembelajaran dirancang dan dijalankan secara profesional. Setiap kegiatan pembelajaran selalu melibatkan dua pelaku aktif, yaitu guru dan siswa. Guru adalah pencipta kondisi belajar siswa yang didesain secara sengaja, sistematis, dan berkesinambungan (fasilitator). Sedangkan siswa sebagai peserta didik merupakan pihak yang menikmati kondisi belajar yang menciptakan guru tersebut (aktor) (Febriani, 2019) (Khotidjah, 2021). Semakin berkembangnya manusia, berkembang pula ilmu pengetahuan dan teknologi di segala bidang. Dewasa ini, istilah teknologi yang sedang berkembang dikenal nama TIK (Teknologi Informasi dan 
Komunikasi). Teknologi Informasi dan Komunikasi (TIK), atau dalam bahasa Inggris dikenal dengan istilah Information and Communication Technologies (ICT), adalah payung besar terminologi yang mencakup seluruh peralatan teknis untuk memproses dan menyampaikan informasi. Jika ditinjau dari asal sebuah kata teknologi. Kata teknologi berasal dari bahasa Yunani, technologia, atau techne yang mempunyai arti 'keahlian' dan logia yang berarti 'pengetahuan' (Murniyati, 2021).

Dalam pengertian yang sempit, teknologi merupakan sesuatu yang mengacu pada objek benda yang dipergunakan untuk kemudahan aktivitas manusia, seperti mesin, perkakas, atau perangkat keras (Ngatmiyatun, 2021). TIK mencakup dua aspek yaitu teknologi informasi dan teknologi komunikasi. Teknologi informasi meliputi segala hal yang berkaitan dengan proses, penggunaan sebagai alat bantu, manipulasi, dan pengelolaan informasi (Pitoyo, 2021). Sedangkan teknologi komunikasi adalah segala sesuatu yang berkaitan dengan penggunaan alat bantu untuk memproses dan mentransfer data dari perangkat yang satu ke lainnya. TIK berperan penting dalam kegiatan pembelajaran pada suatu proses pendidikan. Pendidikan suatu bangsa merupakan tolak ukur kemampuan suatu bangsa (Priyastuti, 2021). Oleh karena itu, pemanfaatan TIK diharapkan dapat meningkatkan kualitas pendidikan kita (Rahmelia, 2021). Salah satu cara pemanfaatan TIK adalah melalui pembelajaran di kelas yang berbasis teknologi dan informasi. Guru sebagai tenaga pengajar yang profesional harus tahu dan paham akan pentingnya TIK dalam pembelajaran pada saat ini. Diharapkan dengan pemanfaatan TIK ini guru dapat meningkatkan mutu pendidikan di indonesia.

Kehadiran TIK dalam pendidikan bisa dimaknai dalam tiga paradigma, yaitu
(1) TIK sebagai alat atau berupa produk teknologi yang bisa digunakan dalam pendidikan, (2) TIK sebagai konten atau sebagai bagian dari materi yang bisa dijadikan isi dalam pendidikan, dan (3) TIK sebagai program aplikasi atau alat bantu untuk manajemen pendidikan yang efektif dan efisien. Ketiga paradigma tersebut disinergikan dalam sebuah kerangka sumberdaya TIK yang secara khusus diposisikan dan diarahkan untuk mencapai visi dan misi pendidikan di Indonesia. Di era globalisasi pendidikan, disadari ataupun tidak, tantangan dunia pendidikan ke depan akan lebih berat. Oleh karena itu, optimalisasi TIK menjadi salah satu alternatif solusi dalam menopang dan menggerakkan dunia pendidikan di kancah persaingan global.

Sebagaimana yang dijelaskan oleh Usman dan Lilis (2001: 4) (S et al., 2021) bahwa penggunaan media di suatu pendidikan merupakan dasar yang sangat penting dan diperlukan yang bersifat melengkapi dan merupakan bagian integral demi berhasilnya proses pendidikan dan pengajaran di sekolah. Untuk mencapai tujuan pendidikan tersebut diperlukan peningkatan kualitas sumber daya manusia (SDM) dan kualitas proses pembelajaran. Salah satu faktor yang mempengaruhi keberhasilan dalam proses pembelajaran adalah penggunaan media pembelajaran, baik benda-benda asli maupun tiruan yang relevan dengan konsep (Sakinah \& Dewi, 2021). Disamping media pembelajaran yang merupakan salah satu sumber belajar yang penting, media pembelajaran juga dapat membantu para guru untuk memperjelas dan memvisualisasikan konsep kepada para peserta didik dalam mencapai ketrampilan tertentu. Sejalan dengan perkembangan zaman dapat ditandai dengan kemajuan ilmu pengetahuan dan tehnologi canggih. Karena itu dalam proses belajar mengajar perlu juga dikembangkan cara cara mengajar yang baru (Saptaningsih \& Astuti, 
2019). Diantaranya yaitu cara mengajar dengan menggunakan media komputer dan salah satunya pengoperasian Microsoft Power Point (Sakti \& Hartanto, 2020).

Berdasarkan pengamatan awal yang penulis lakukan di SD Negeri 2 Saradan Tahun Pelajaran 2019/2020 maka penulis menemukan masalah-masalah para guru SD Negeri 2 Saradan sebagai berikut: 1) Kemampuan para guru dalam menggunakan Microsoft power point sebagai media pembelajaran masih rendah; 2) Kualitas proses pembelajaran dengan menggunakan media slide Power Point pembelajaran yang sudah dibuat oleh guru masih belum optimal; dan 3) Para guru kurang termotivasi dan belum percaya diri dalam menggunakan slide Microsoft PowerPoint sebagai media pembelajaran. Sedangkan secara empiris diperoleh fakta bahwa tidak ada guru yang kemampuanya masuk kualifikasi Amat Baik, hanya 2 orang guru $(25,0 \%)$ yang kualifikasinya Baik, ada 4 orang guru $(50,0 \%)$ yang kualifikasinya Cukup dan masih ada 2 orang guru $(25,0 \%)$ yang kualifikasinya Kurang.

Dengan masih banyaknya guru yang belum mampu menggunakan komputer dan menguasai TIK dalam proses pembelajaran, maka perlu adanya pelatihan teknis TIK bagi semua guru agar mampu meningkatkan kompetensi mengajarnya (Rachman et al., 2021). Untuk mengatasi masalah yang dialami guru-guru tersebut, peneliti selaku kepala SDN 2 Saradan akan melaksanakan Penelitian Tindakan Sekolah dengan menggunakan in service training secara intensif dan optimal untuk meningkatkan kompetensi guru dalam menguasai TIK dalam proses pembelajaran di SDN 2 Saradan pada semester 1 Tahun Pelajaran 2019/2020.

Program in service training adalah suatu usaha pelatihan atau pembinaan yang memberi kesempatan kepada seseorang yang mendapat tugas jabatan tertentu dalam hal tersebut adalah guru, untuk mendapat pengembangan kinerja. In service training juga bisa dikatakan sebagai suatu program sekaligus metode pelatihan dan pendidikan dalam jabatan yang dilaksanakan dengan cara langsung bekerja di tempat untuk belajar dan meniru suatu pekerjaan dibawah bimbingan seorang pengawas (Purwanto, 2012:96). Dalam kegiatan in-service training, guru dibimbing secara langsung dan intens untuk membantu belajar lebih efektif, sehingga diharapkan kompetensi guru dalam menguasai TIK dalam proses pembelajaran akan meningkat (Widodo, 2021).

Dengan penerapan in-service training diharapkan; (1) guru memahami menguasai TIK dalam proses pembelajaran secara keseluruhan, (2) guru mengaplikasikan menguasai TIK dalam proses pembelajaran dalam proses pembelajaran, (Nurgiansah \& Al Muchtar, 2018)(Nurgiansah et al., 2021)(Dewantara et al., 2021) dan (3) guru dapat meningkat kualitas kinerjanya. Hal lain yang mendukung dengan diterapkannya TIK dalam proses pembelajaran yaitu di dalam dunia pendidikan di Indonesia, ada beberapa alasan problematik yang melatarbelakangi pentingnya pemanfaatan TIK, terutama dalam (1) meningkatkan mutu pendidikan di semua jenjang, (2) mengatasi kesenjangan layanan pendidikan akibat kondisi geografis yang mana jika diabaikan akan menimbulkan disparitas mutu layanan, dan (3) perubahan sosiobudaya masyarakat yang bergerak dinamis, dan (4) memupuk rasa nasionalisme untuk menjaga kesatuan dan persatuan bangsa (Sigit \& Andari, 2019) (Sumarni, 2021).

Mengacu pada uraian yang sudah dipaparkan sebelumnya, maka peneliti tertarik untuk mengadakan penelitian tindakan sekolah dengan judul "Upaya Meningkatkan Kemampuan Guru Dalam Menggunakan Program Power Point Presentation Sebagai Media Pembelajaran melalui in-service training di SDN 2 
Saradan Semester I Tahun Pelajaran 2019/2020".

\section{METODE PENELITIAN}

Penelitian tindakan ini dilaksanakan pada semester 2 tahun pelajaran 2019/2020 selama empat bulan. Penelitian dimulai bulan Juli 2019 hingga bulan Oktober 2019. Lokasi tempat penelitian adalah di SD Negeri 2 Saradan yang Dusun Jarum Desa saradan Kecamatan Baturetno, Kabupaten Wonogiri. Alasan pemilihan tempat penelitian ini adalah karena peneliti melihat adanya indikasi rendahnya kemampuan guru SD Negeri 2 Saradan Tahun Pelajaran 2019/2020 dalam menggunakan Program Power Point Presentation (PPT) sebagai media pembelajaran. Kedudukan peneliti dalam penelitian ini adalah selaku pelaksana tindakan serta pengumpul data.

Subjek penelitian ini adalah guru SD Negeri 2 Saradan Tahun Pelajaran 2019/2020 dengan jumlah 8 orang. Sedangkan objek penelitian ini adalah kemampuan guru SD Negeri 2 Saradan Tahun Pelajaran 2019/2020 dalam menggunakan Program Power Point Presentation (PPT) sebagai media pembelajaran melalui In Service Training . Banyaknya data dalam penelitian ini ada tiga macam yaitu: 1) Data hasil penilaian kemampuan guru pada kondisi awal sebelum pelaksanaan PTS, 2) Data hasil penilaian kemampuan guru pada siklus I, dan 3) Data hasil penilaian kemampuan guru pada siklus II.

Teknik pengumpulan data dalam peneltian ini yaitu observasi dengan menggunakan instrument penilaian berupa lembar penilaian (Nurgiansah, 2021b)(Nurgiansah, 2021a). Supaya data yang digunakan dalam penelitian ini dapat dipertanggungjawabkan keabsahannya, maka perlu dilakukan validasi data. Validasi data hasil penilaian kemampuan guru dalam menggunakan Program Power Point Presentation (PPT) sebagai media pembelajaran menggunakan triangulasi data, yaitu peneliti mengkonfirmasikan hasil penilaiannya kepda guru yang dinilai. Selanjutnya, analisis data kemampuan guru dalam menggunakan Program Power Point Presentation (PPT) sebagai media pembelajaran pada kondisi awal, siklus I dan siklus II dilakukan dengan menggunakan analisis deskriptif komparatif. Analisis deskriptif komparatif dilakukan pada siklus I dan siklus II. Analisis data siklus I dilakukan dengan membandingkan hasil penilaian kemampuan guru kondisi awal dengam nilai hasil penilaian kemampuan guru pada siklus I. Sedangkan analisis data siklus II dilakukan dengan membandingkan hasil penilaian kemampuan guru pada siklus I dengan hasil penilaian kemampuan guru pada siklus II.

Keberhasilan suatau penelitian dapat dilihat dari pencapaian indikator kinerja. Indikator kerja dapat dilihat secara umum dengan membandingkan hasil penilaian kemampuan guru dari satu siklus ke siklus berikutnya. Indikator kinerja penelitian ini adalah sebagai berikut:1) Adanya peningkatan kemampuan guru dalam menggunakan Program Power Point Presentation (PPT) sebagai media pembelajaran dari kondisi awal ke siklus I, dan dari siklus I ke siklus II. 2) Semua guru SD Negeri 2 Saradan kemampuan dalam menggunakan Program Power Point Presentation (PPT) sebagai media pembelajaran minimal mencapai kualifikasi Baik. Kualifikasi penilaian kemampuan guru dalam menggunakan Program Power Point Presentation (PPT) sebagai media pembelajaran adalah sebagai berikut.

Tabel 1. Kualifikasi Penilaian Kemampuan Guru

\begin{tabular}{|c|c|c|}
\hline No & Kualifikasi & Range Nilai \\
\hline 1. & Amat Baik & $91-100$ \\
\hline 2. & Baik & $71-90$ \\
\hline 3. & Cukup & $51-70$ \\
\hline
\end{tabular}




\section{\begin{tabular}{l|l|l}
4. & Kurang & $\leq 50$
\end{tabular}}

HASIL PENELITIAN DAN PEMBAHASAN Hasil Penelitian

Kondisi Awal/Pra Tindakan

A. Deskripsi Kondisi Awal

Gambaran kondisi awal tentang kompetensi guru dalam kemampuan guru Menggunakan Program Power Point Presentation Sebagai Media Pembelajaran dalam pembelajaran diperoleh melalui observasi pra siklus yang dilaksanakan oleh peneliti pada bulan Juli 2019. Berdasarkan hasil rekaman fakta/ observasi di lapangan, pada awalnya kompetensi guru dalam kemampuan guru Menggunakan Program Power Point Presentation Sebagai Media Pembelajaran dalam pembelajaran belum sesuai harapan. Hasil observasi peneliti selaku Kepala SD Negeri 2 Saradan pada semester 1 Tahun Pelajaran 2019/2020 pada saat Kegiatan Belajar Mengajar (KBM) berlangsung, terlihat beberapa atau sebagian besar peserta didik belum mampu mengikuti proses pembelajaran secara optimal. Selama proses pembelajaran, potensi para siswa kurang diberdayakan sehingga sebagian besar siswa belum mampu mencapai kompetensi individual yang diperlukan untuk mengikuti pelajaran lanjutan. Beberapa siswa belum belajar sampai pada tingkat pemahaman. Siswa belum mampu mempelajari atau menghafal fakta, konsep, prinsip, hukum, teori, dan gagasan inovatif lainnya pada tingkat ingatan, peserta didik belum dapat menggunakan dan menerapkannya secara efektif dalam pemecahan masalah seharihari yang kontekstual. Hal ini menunjukkan bahwa proses pembelajaran yang terjadi di dalam kelas selama ini masih menggunakan proses pembelajaran konvensional, belum mengarah kepada kemampuan guru Menggunakan Program Power Point Presentation Sebagai Media Pembelajaran dalam pembelajaran

\section{Pembahasan}

Adapun tabel hasil penilaian kompetensi guru dalam kemampuan guru Menggunakan Program Power Point Presentation Sebagai Media Pembelajaran dalam pembelajaran pada kondisi awal dapat dilihat pada tabel berikut.

Tabel 2 Hasil Penilaian Kompetensi Guru Pada Kondisi Awal

\begin{tabular}{|c|l|c|}
\hline No & Kualifikasi & Jumlah \\
\hline 1 & Amat Baik & - \\
2 & Baik & 2 orang \\
3 & Cukup & $(25,0 \%)$ \\
4 & Kurang & 3 orang \\
& & $(37,5 \%)$ \\
& & 3 orang \\
& & $(37,5 \%)$ \\
\hline \multicolumn{2}{|c|}{ Rata-rata } & $\mathbf{5 9 , 7}$ \\
\hline & Predikat & Cukup \\
\hline
\end{tabular}

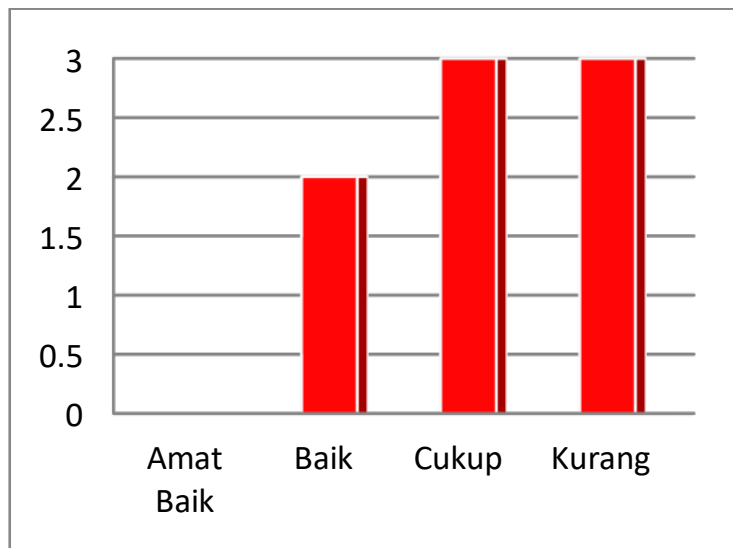

Gambar 1. Grafik Hasil Penilaian Kompetensi Guru pada Kondisi Awal

Pada kondisi awal, sebelum diterapkan In-service training, tidak ada guru yang kompetensi kemampuan guru Menggunakan Program Power Point Presentation Sebagai Media Pembelajaran dalam pembelajaran masuk kualifikasi Amat Baik, hanya 2 orang guru $(25,0 \%)$ yang kompetensinya masuk kualifikasi Baik, 3 orang guru $(37,5 \%)$ yang kompetensinya masuk kualifikasi Cukup dan masih ada 3 orang guru $(37,5 \%)$ yang kompetensinya masuk kualifikasi Kurang. Nilai rata-rata kompetensi guru adalah 
59,7 dengan kualifikasi Cukup. Artinya sebagian besar guru belum memahami kemampuan guru Menggunakan Program Power Point Presentation Sebagai Media Pembelajaran dalam pembelajaran dan belum menerapkan kemampuan guru Menggunakan Program Power Point Presentation Sebagai Media Pembelajaran dalam pembelajaran dalam kegiatan pembelajaran di kelas.

Untuk mengatasi permasalahan rendahnya kompetensi guru SD Negeri 2 Saradan Tahun Pelajaran 2019/2020 dalam kemampuan guru Menggunakan Program Power Point Presentation Sebagai Media Pembelajaran dalam pembelajaran , maka peneliti akan melaksanakan suatu Penelitian Tindakan Sekolah melalui inservice training.

\section{Siklus I}

Pengamatan terhadap pelaksanaan tindakan, yaitu menitikberatkan pada kompetensi guru dalam kemampuan guru Menggunakan Program Power Point Presentation Sebagai Media Pembelajaran dalam pembelajaran setelah diterapkan Inservice training dengan bimbingan kelompok dan individu. Kegiatan guru peserta diobservasi, baik menyangkut kesiapan mental dan fisik guru, kehadiran guru, kualitas pembelajaran setelah Inservice training. Dari hasil pengamatan terhadap aktivitas guru peserta dengan menggunakan lembar observasi yang telah disiapkan, diperoleh data sebagai berikut.

\section{Tabel 3 Hasil Penilaian Kompetensi Guru Pada} Siklus I

\begin{tabular}{|c|l|c|}
\hline No & Kualifikasi & Jumlah \\
\hline 1 & Amat Baik & 2 orang \\
2 & Baik & $(25,0 \%)$ \\
3 & Cukup & 3 orang \\
4 & Kurang & $(37,5 \%)$ \\
& & 3 orang \\
& & $(37,5 \%)$ \\
& & - \\
\hline
\end{tabular}

\begin{tabular}{|c|c|}
\hline Rata-rata & $\mathbf{7 3 , 9}$ \\
\hline Predikat & Baik \\
\hline
\end{tabular}

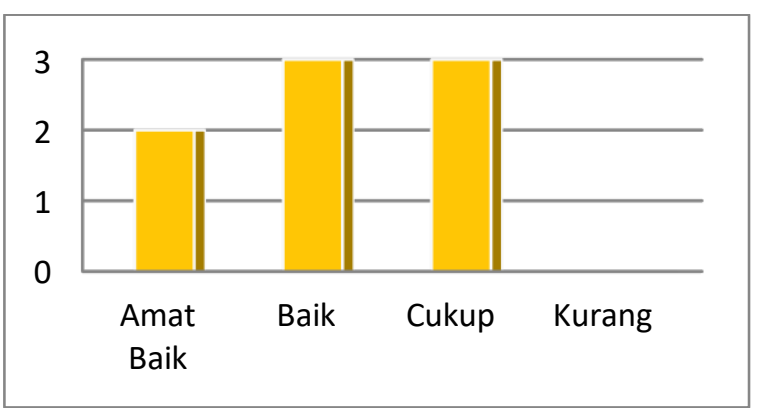

Gambar 2. Grafik Hasil Penilaian Kompetensi Guru pada Siklus I

Pada siklus I, kepala sekolah sudah melaksanakan In-service training dengan bimbingan kelompok dan individu. Ada 2 orang guru $(25,0 \%)$ yang kompetensi kemampuan guru Menggunakan Program Power Point Presentation Sebagai Media Pembelajaran dalam pembelajaran masuk kualifikasi Amat Baik, 3 orang guru $(37,5 \%)$ yang kompetensinya masuk kualifikasi Baik, 3 orang guru $(37,5 \%)$ yang kompetensinya masuk kualifikasi Cukup dan tidak ada guru yang kompetensinya masuk kualifikasi Kurang. Nilai rata-rata kompetensi guru adalah 73,9 dengan kualifikasi Baik. Artinya sebagian guru sudah memahami dan menerapkan kemampuan guru Menggunakan Program Power Point Presentation Sebagai Media Pembelajaran dalam pembelajaran tetapi sebagian belum memahami dan menerapkan kemampuan guru Menggunakan Program Power Point Presentation Sebagai Media Pembelajaran dalam pembelajaran dalam kegiatan pembelajaran di kelas.

Kompetensi guru SD Negeri 2 Saradan dalam kemampuan guru Menggunakan Program Power Point Presentation Sebagai Media Pembelajaran dalam pembelajaran pada siklus I sudah menunjukkan peningkatan, namun peningkatannya masih belum memenuhi kriteria indikator kinerja penelitian. Dari 
data tersebut menunjukkan bahwa melalui penerapan In-service training dapat meningkatkan kompetensi guru SD Negeri 2 Saradan dalam kemampuan guru Menggunakan Program Power Point Presentation Sebagai Media Pembelajaran dalam pembelajaran . Namun, karena peningkatan kompetensi guru pada siklus I belum memenuhi semua kriteria indikator kinerja apenelitian, yaitu belum semua guru SD Negeri 2 Saradan kompetensinya masuk kualifikasi Baik. Maka peneliti memutuskan untuk melanjutkan tindakan ke siklus II.

\section{Siklus 2}

Pada siklus II, kepala sekolah menerapkan In-service training dengan diskusi dan micro teaching. Sesuai dengan refleksi hasil siklus I, langkah-langkah yang diambil pada dasarnya memiliki prosedur yang sama dengan siklus I, hanya saja diadakan perbaikan pada hal-hal yang dilihat ada kelemahan serta mempertahankan hal-hal yang sudah berjalan dengan baik. dengan memfokuskan pada penjelasan aspekaspek yang belum dipahami guru lebih menitikberatkan pada aspek pembimbingan secara kelompok. Hasil penilaian kompetensi guru SD Negeri 2 Saradan dalam kemampuan guru Menggunakan Program Power Point Presentation Sebagai Media Pembelajaran dalam pembelajaran dapat dilihat pada tabel berikut.

$T$

Tabel 4 Hasil Penilaian Kompetensi Guru Pada Siklus II

\begin{tabular}{|c|l|c|}
\hline No & Kualifikasi & Jumlah \\
\hline 1 & Amat Baik & 3 orang \\
2 & Baik & $(37,5 \%)$ \\
3 & Cukup & 5 orang \\
4 & Kurang & $(62,5 \%)$ \\
& & - \\
& & - \\
\hline & Rata-rata & $\mathbf{8 3 , 8}$ \\
\hline & Predikat & Baik \\
\hline
\end{tabular}

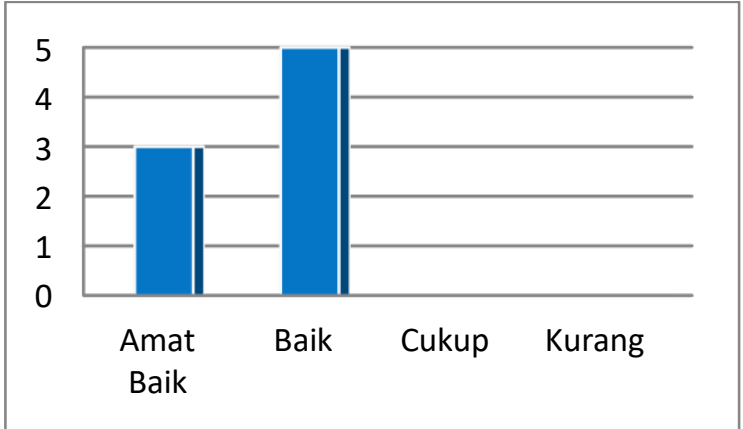

Gambar 3. Grafik Hasil Penilaian Kompetensi Guru pada Siklus II

Pada siklus II, kepala sekolah menerapkan In-service training dengan diskusi dan micro teaching. Ada 3 orang guru $(37,5 \%)$ yang kompetensinya masuk kualifkasi Amat Baik, sebanyak 5 orang guru $(62,5 \%)$ yang kompetensinya masuk kualifikasi Baik dan tidak ada guru yang kualifikasi Cukup maupun Kurang. Nilai rata-rata kompetensi guru adalah 83,8 masuk kualifikasi Baik. Artinya semua guru sudah memahami dan sudah menerapkan kemampuan guru Menggunakan Program Power Point Presentation Sebagai Media Pembelajaran dalam pembelajaran dalam kegiatan pembelajaran di kelas. Pada siklus II, kepala sekolah menerapkan In-service training dengan diskusi dan micro teaching. Ada 3 orang guru $(37,5 \%)$ yang kompetensinya masuk kualifkasi Amat Baik, sebanyak 5 orang guru $(62,5 \%)$ yang kompetensinya masuk kualifikasi Baik dan tidak ada guru yang kualifikasi Cukup maupun Kurang. Nilai rata-rata kompetensi guru adalah 83,8 masuk kualifikasi Baik. Artinya semua guru sudah memahami dan sudah menerapkan kemampuan guru Menggunakan Program Power Point Presentation Sebagai Media Pembelajaran dalam pembelajaran dalam kegiatan pembelajaran di kelas. Jadi, melalui penerapan In-service training dapat meningkatkan kompetensi guru SD Negeri 2 Saradan pada semester 1 Tahun Pelajaran 2019/2020 dalam kemampuan guru Menggunakan Program Power Point Presentation Sebagai Media Pembelajaran 
dalam pembelajaran dari kondisi siklus I nilai rata-rata kompetensi guru adalah 73,9 masuk kualifikasi Baik, meningkat pada siklus II nilai rata-rata kompetensi guru menjadi 83,8 masuk kualifikasi Baik. Peningkatan kompetensi guru pada siklus II sudah berhasil memnuhi kriteria indikator kinerja penelitian, maka peneliti memutuskan untuk menghentikan tindakan penelitian ini.

\section{DAFTAR PUSTAKA}

Agus, 2006. Manajemen Kerja Prestasi. Jakarta: Rajawali.

Arif S. Sadiman, dkk. 2011. Media Pendidikan, Pengertian, Pengembangan, dan Pemanfaatannya. Jakarta: PT. Raja Grafindo Persada.

Arsyad, Azhar. 2014. Media Pembelajaran, Edisi Revisi. Jakarta: PT. RajaGrafindo Persada.

Bashori, K. (2015). Pengembangan KapasitasGuru. Jakarta: Pustaka Alvab

Benny, Pribadi dan Yuni Katrin. 2006. Media Teknologi, Jakarta: Rineka Cipta

Bernawi Munthe, 2009. Desain Pembelajaran, Yogyakarta: Pustaka Insan Madani.

Burgess, R. G., Connor, J., Galloway, S.,Morrison, M., \& Newton, M. (2013).Implementing Inservice education andtraining. Routledge.

Daryanto. 2011. Penelitian Tindakan Kelas dan Penelitian Tindakan Sekolah. Yogyakarta: GAVA MEDIA.

Depdiknas. 2005. Peraturan Pemerintah (PP) Nomor 74 Tahun 2008 tentang Guru dan Dosen Dina Indriana. 2011. Ragam Alat Bantu Media Pengajaran. Jogjakarta: Diva Perss.

Erlina. 2009. Supermedia Mencari dan Menampilkan Sumber Mengajar dari. Internet. Jakarta : Erlangga

Dewantara, J. A., Hermawan, Y., Yunus, D., Prasetiyo, W. H., Efriani, Arifiyanti, F., \& Nurgiansah, T. H. (2021). Anti-Corruption Education as an Effort to Form Students With Character Humanist and Law-Compliant. Jurnal Civics: Media Kajian Kewarganegaraan, 18(1), 7081.

Febriani, N. W. (2019). Pendekatan Saintifik Sebagai Konsep Dasar Pembelajaran Siswa di Sanggar Anak Alam (SALAM) Nitiprayan Yogyakarta. Jurnal Kewarganegaraan, 3(1), 3540.

Khotidjah, D. (2021). Peningkatan Penggunaan Past Tense Dalam Text Recount Melalui Model STAD pada Siswa. Jurnal Kewarganegaraan, 5(1), 86-91.

Murniyati, M. (2021). Peningkatan Kemampuan Menyusun Rpp Pembelajaran Kooperatif Melalui Program Supervisi Akademik Bagi Guru Kelas. Jurnal Kewarganegaraan, 5(1), 7176. https://journal.upy.ac.id/index.php/pkn/article/view/1330

Ngatmiyatun, B. (2021). Peningkatan Kemampuan Penggunaan Microsoft Office 365 Melalui Pelatihan Dan Simulasi Pada Guru Sekolah Dasar. Jurnal Kewarganegaraan, 5(1), 77-85.

Nurgiansah, T. H. (2021a). Partisipasi Politik Masyarakat Sleman di Masa Pandemi Covid-19 dalam Konteks Pendidikan Kewarganegaraan. Jurnal Civic Hukum, 6(1), 1-9.

Nurgiansah, T. H. (2021b). Petuah Pendidikan Kewarganegaraan Dalam Kontestasi Politik. AoEJ: Academy of Education Journal, 12(1), 39-47.

Nurgiansah, T. H., \& Al Muchtar, S. (2018). Development of Student Awareness through Student Learning Model Jurisprudential in Citizenship Education. ATLANTIS PRESS, 251(Acec), 670-674. https://doi.org/10.2991/acec-18.2018.150

Nurgiansah, T. H., Pratama, F. F., \& Iman, A. S. (2021). Penelitian Tindakan Kelas Dalam 
Pendidikan Kewarganegaraan. Jurnal Pendidikan Pancasila Dan Kewarganegaraan, 2(1), 10-23.

Pitoyo, S. J. (2021). Upaya Meningkatkan Kompetensi Penyusunan RPP Berkarakter Melalui Praktik Unjuk Kerja. Jurnal Kewarganegaraan, 5(1), 120-126.

Priyastuti, K. E. (2021). Upaya Meningkatkan Hasil Belajar Siswa Menggunakan Metode Snowball Throwing. Jurnal Kewarganegaraan, 5(1), 92-100.

Rachman, F., Nurgiansah, T. H., \& Kabatiah, M. (2021). Profilisasi Pendidikan Kewarganegaraan dalam Kurikulum Pendidikan Indonesia. Edukatif: Jurnal Ilmu Pendidikan, 3(5), 2970-2984.

Rahmelia, S. (2021). Pemaknaan Mahasiswa Terhadap Narasi Konflik Beragama. Jurnal Kewarganegaraan, 5(1), 45-54.

S, H. C., Alamsyah, M., Izzrufi, M. I., L, S. R., \& Saepudin, E. (2021). Persepsi Mahasiswa/i Terhadap Wacana Amandemen UUD NRI 1945 (Survei terhadap Mahasiswa STEI ITB Angkatan 2018). Jurnal Kewarganegaraan, 5(1), 13-20.

Sakinah, R. N., \& Dewi, D. A. (2021). Implementasi Nilai-Nilai Pancasila Sebagai Karakter Dasar Para Generasi Muda Dalam Menghadapi Era Revolusi Industrial 4 . 0. Jurnal Kewarganegaraan, 5(1), 152-167.

Sakti, R. O., \& Hartanto, S. (2020). Meningkatkan Prestasi Belajar Ppkn Dengan Menggunakan Model Brain Based Learning. Jurnal Kewarganegaraan, 4(1), 38-44. https://journal.upy.ac.id/index.php/pkn/article/view/1171

Saptaningsih, R. I., \& Astuti, W. (2019). Peranan Yayasan Annisa Swasti (Yasanti) Dalam Upaya Perlindungan Dan Pemberdayaan Buruh Gendong Perempuan Di Pasar Beringharjo Yogyakarta. Jurnal Kewarganegaraan, 3(1), 46-55. https://doi.org/10.31316/jk.v3i1.512

Sigit, H., \& Andari, R. (2019). Penyelesaian Sengketa Tanah Melalui Mediasi Di Kantor Pertanahan Kabupaten Kulon Progo. Jurnal Kewarganegaraan, 3(1), 41-45. https://doi.org/10.31316/jk.v3i1.510

Sumarni. (2021). Model Pembelajaran Make a Match Untuk Meningkatkan HAsil Belajar Penyesuaian Diri dengan Lingkungan pada Siswa. Jurnal Kewarganegaraan, 5(1), 39-44.

Widodo, M. (2021). Upaya Meningkatkan Kompetensi Guru dalam Penguasaan Kurikulum 2013 Melalui In Service Learning. Jurnal Kewarganegaraan, 5(1), 113-119. 